\title{
A pivotal role for Pim-1 kinase in esophageal squamous cell carcinoma involving cell apoptosis induced by reducing Akt phosphorylation
}

\author{
SHENGLEI LI ${ }^{1}$, YU XI $^{2}$, HONGYAN ZHANG $^{1}$, YANGE WANG $^{3}$, XIN WANG $^{4}$, \\ HONGTAO LIU ${ }^{2}$ and KUISHENG CHEN ${ }^{1}$
}

${ }^{1}$ Department of Pathology, the First Affiliated Hospital of Zhengzhou University; Henan Key Laboratory of Tumor Pathology, Zhengzhou, Henan 450052; ${ }^{2}$ Laboratory for Cell Biology, Department of Bioengineering of Zhengzhou University, Zhengzhou, Henan $450001 ;{ }^{3}$ Laboratory for Cell Biology and Genetics, Medical College of Henan University, Kaifeng, Henan 475004; ${ }^{4}$ Department of Oncology, the First Affiliated Hospital of Zhengzhou University, Zhengzhou, Henan 450052, P.R. China

Received May 28, 2010; Accepted July 2, 2010

DOI: 10.3892/or_00000947

\begin{abstract}
It is well documented that Provirus integration site for Moloney murine leukemia virus 1 (Pim-1), as a protooncogene encoding a serine/threonine kinase with multiple cellular functions, is tightly associated with the occurrence and development of tumors. Overexpression of Pim-1 plays a critical role in the progression of several different tumors. In this study, esophageal squamous cell carcinoma (ESCC) EC9706 cells with Pim-1 siRNA treatment resulted in a clear decrease of Pim-1 levels, followed by inhibiting cell proliferation and inducing apoptosis. Further, Pim-1 siRNA reduced phosphorylation of Akt and Bad, and increased cleaved caspase-3/-9 activities and expression levels. These data suggest that Pim-1 siRNA-mediated apoptosis is closely related to the decrease in Akt and Bad phosphorylation and increase in cleaved caspase-3/-9 activities, and thus manipulation of Pim-1 is a potential target for molecular therapy in the clinical treatment of patients with ESCC.
\end{abstract}

\section{Introduction}

Esophageal squamous cell carcinoma (ESCC), the major histological form of esophageal cancer, is the sixth most

Correspondence to: Dr Hongtao Liu, Laboratory for Cell Biology, Department of Bioengineering of Zhengzhou University, Zhengzhou, Henan 450001, P.R. China

E-mail: liuht1230@126.com

Dr Kuisheng Chen, Department of Pathology, the First Affiliated Hospital of Zhengzhou University; Henan Key Laboratory of Tumor Pathology, Zhengzhou, Henan 450052, P.R. China E-mail: chenksh2002@yahoo.com.cn

Key words: esophageal squamous cell carcinoma, provirus integration site for Moloney murine leukemia virus 1, small interfering RNA, cell apoptosis, Akt phosphorylation frequent cause of cancer deaths worldwide (1). ESCC shows a poor prognosis due to the lack of early screening strategy and is often presented in an advanced stage at the time of diagnosis (2). ESCC is one of the most frequently diagnosed cancers in developing countries, especially in China (3). Currently, although therapy strategies have been improved, the prognosis of patients with ESCC is still poor and 5-year survival rate for ESCC appears a dramatic decrease (4). Obviously, there is a clear need to seek for new molecular prognostic markers that helps identify patients at a higher risk of death and improve the prognosis of patients with ESCC.

Provirus integration site for Moloney murine leukemia virus 1 (Pim-1) was originally identified as a preferential proviral integration site in Moloney murine leukemia virusinduced T cell lymphomas (5) and the first described member of the Pim kinase family, including another two serine/ threonine kinases Pim-2 and Pim-3 (6). More and more evidence has demonstrated that Pim-1, a proto-oncogene encoding a serine/threonine protein kinase, plays an essential role in cell survival, cell proliferation, cell differentiation, cell cycle, and cell apoptosis (7-14), especially in the occurrence and development of tumors (15-20). Therefore, the rapidly increasing knowledge on the role of the Pim-1 in cancer will hopefully provide useful molecular markers for detection and prognosis of tumor.

However, the role for Pim-1 in ESCC has not yet been reported. Therefore, the purpose of this study was to analyze the effect of Pim-1 siRNA on Pim-1 expression levels in ESCC cell line EC9706 cells by RT-PCR and Western blotting methods, and subsequently, to investigate the effect of Pim-1 siRNA on cell proliferation and apoptosis in EC9706 cells in vitro. Further, Akt and Bad phosphorylation levels, caspase-3/-9 activities, and cleaved caspase-3/-9 expression levels were investigated to elucidate the mechanism of cell apoptosis mediated by Pim-1 siRNA. The findings presented herein will provide the first new data for future therapy of ESCC. 


\section{Materials and methods}

Cell line and cell culture. ESCC cell line EC9706 cells were provided by the State Key Laboratory of Molecular Oncology, Chinese Academy of Medical Sciences (Beijing, China). The cells were cultured in RPMI-1640 medium (Gibco, USA) supplemented with $10 \%$ fetal bovine serum (FBS) (HyClone Laboratories, Logan, USA), $100 \mathrm{U} / \mathrm{ml}$ penicillin and $100 \mu \mathrm{g} / \mathrm{ml}$ streptomycin at $37^{\circ} \mathrm{C}$ in the presence of $5 \% \mathrm{CO}_{2}$, as described in the previous studies from our laboratory $(21,22)$.

siRNA transfection. Pim-1 siRNA and control siRNA were purchased from Santa Cruz Company (CA, USA). The cells were incubated at $37^{\circ} \mathrm{C}$ in a $\mathrm{CO}_{2}$ incubator until $60-80 \%$ confluent, subsequently, siRNAs $(\sim 50 \mathrm{nmol} / \mathrm{l})$ were transfected with Lipofectamine ${ }^{\mathrm{TM}} 2000$ (Invitrogen) into EC9706 cells in a six-well culture plate according to manufacturer's protocol. At $48 \mathrm{~h}$ after transfection, EC9706 cells were harvested and subjected to flow cytometry detection, RTPCR, Western blot and immunocytochemisty analysis as described below. At different time points $(24,48,72$, and $96 \mathrm{~h})$ after transfection, cells were harvested for cell proliferation analysis.

Immunocytochemical analysis. The immunoreactivity of Pim-1 in EC9706 cells was determined using SP kit (Santa Cruz Company) according to the manufacturer's instructions. Briefly, EC9706 cells untreated and transfected with Pim-1 siRNA and control siRNA were inoculated on several sterile glass slides and incubated at $37^{\circ} \mathrm{C}$ for $48 \mathrm{~h}$ in the presence of $5 \% \mathrm{CO}_{2}$. The slides were rinsed 3 times with phosphatebuffered saline (PBS, $\mathrm{pH} 7.4$ ) and fixed with $4 \%$ formaldehyde at room temperature (RT) for $10 \mathrm{~min}$. Subsequently, the slides with EC9706 cells were treated with $3 \% \mathrm{H}_{2} \mathrm{O}_{2}$ for $10 \mathrm{~min}$, the cells were blocked with $5 \%$ normal goat serum for $30 \mathrm{~min}$ in a humidified box at RT, and then incubated with anti-human Pim-1 antibody (1:100) as well as PBS as a control, at $4^{\circ} \mathrm{C}$ overnight, and incubated with corresponding secondary antibody for $30 \mathrm{~min}$, they were developed with a $0.03 \%$ DAB solution. Finally, photomicrographs (magnification, $\mathrm{x} 400$ ) were taken immediately.

Cell proliferation assay. Cell proliferation was determined using WST-8 dye (Beyotime Institute of Biotechnology, China) according to manufacturer's instructions. Briefly, $5 \times 10^{3}$ EC9706 cells/well was seeded in a 96-well cell culture plate, grown at $37^{\circ} \mathrm{C}$ for $24 \mathrm{~h}$, and then placed in serum-starved conditions for a further $6 \mathrm{~h}$. Subsequently, EC9706 cells were transfected with Pim-1 siRNA and control siRNA, respectively. On the day of measuring the growth rate of untreated and treated cells $(24,48,72$, and $96 \mathrm{~h}$, respectively), $100 \mu \mathrm{l}$ of spent medium was replaced with an equal volume of fresh medium containing $10 \%$ CCK-8, then cells were incubated at $37^{\circ} \mathrm{C}$ for $2 \mathrm{~h}$, and the absorbance was finally determined at $450 \mathrm{~nm}$ using a microplate reader.

Cell apoptosis detection. EC9706 cells untreated and transfected with Pim-1 siRNA and control siRNA were trypsinized at $48 \mathrm{~h}$, and washed with cold PBS, then resuspended in PBS.
Annexin V-FITC (BD Biosciences, USA) at final concentration of $1 \mu \mathrm{g} / \mathrm{ml}$ and $250 \mathrm{ng}$ of propidium iodide were added to a mixture containing $100 \mu \mathrm{l}$ of cell resuspension and binding buffer (BD Biosciences) each. After cells were vortexed and incubated for $15 \mathrm{~min}$ at $\mathrm{RT}$ in the dark, $400 \mu \mathrm{l}$ of binding buffer was added to the mixture for flow cytometric analysis using Becton Dickinson FACScan Flow Cytometer (FACScan, Becton Dickinson, Mountain View, USA).

Measurement of caspase activity. EC9706 cells untreated and transfected with Pim-1 siRNA and control siRNA were harvested and centrifuged at $1500 \mathrm{rpm}$ for $10 \mathrm{~min}$. Cells were washed 2 times with PBS ( $\mathrm{pH} 7.4)$ and then resuspended with $50 \mu 1$ lysis buffer at $4^{\circ} \mathrm{C}$ and incubated on ice for $10 \mathrm{~min}$. All the following steps were performed on ice. Cell extracts $(30 \mu \mathrm{g})$ were diluted to $100 \mathrm{ml}$ with $50 \mu \mathrm{l}$ of $2 \mathrm{X}$ reaction buffer (40 mM PIPES, pH 7.2, $200 \mathrm{mM} \mathrm{NaCl,} 2$ mM EDTA, $0.2 \%$ CHAPS, $20 \%$ sucrose and $20 \mathrm{mM}$ DTT), and incubated for $30 \mathrm{~min}$ at $37^{\circ} \mathrm{C}$ with $10 \mu \mathrm{M}$ of fluorogenic caspase substrates of caspase-3 and -9 (Ac-DEVD-AMC and AcLEHD-AFC), respectively. After overnight incubation in dark at $37^{\circ} \mathrm{C}$, samples were read in a microplate reader at $405 \mathrm{~nm}$. The data represent the mean $\pm \mathrm{SD}$ from three separate experiments. The results are expressed as fold induction.

Semi-quantitative RT-PCR. Total RNAs were extracted from EC9706 cells untreated and transfected with Pim-1 siRNA and control siRNA by TRIzol reagent (Invitrogen) according to the manufacturer's instructions, and then subjected to firststrand cDNA synthesis with AMV first strand DNA synthesis kit (Biotech Co., Shanghai, China). Pim-1 (F: 5-GCGCTGC TCAAGGACACCGT-3; R: 5-GGCGACAGGCTGTGGA GGTG-3, product size is $356 \mathrm{bp}$ ) and 3 -actin (F: 5'-CGA CAACGGCTCCGGCATGT-3'; R: 5'-TGGGCCTCGTCG CCCACATA-3', product size is $147 \mathrm{bp}$ ) (internal control) primers were designed to amplify the specific band using the procedures described as follows: initial denaturation at $94^{\circ} \mathrm{C}$ for $2 \mathrm{~min}$, followed by $30 \mathrm{sec}$ at $94^{\circ} \mathrm{C}, 30 \mathrm{sec}$ at $55^{\circ} \mathrm{C}$, and $30 \mathrm{sec}$ at $72^{\circ} \mathrm{C}$ for a total of 30 cycles and a terminal extension at $72^{\circ} \mathrm{C}$ for $6 \mathrm{~min}$. After amplification, $5 \mu \mathrm{l}$ of PCR products were resolved on a $1 \%$ agarose gel. DNA bands were visualized by UV light and documented with a Gene Tools (model: P67UA). Semi-quantitative analysis of band intensity was performed with Gene Tools software (UVP, Inc., Upland, CA, USA).

Western blot analysis. Western blot was performed according to published methods (22). Briefly, EC9706 cells untreated and transfected with Pim-1 siRNA and control siRNA were harvested at $48 \mathrm{~h}$ after treatment and lysed for $20 \mathrm{~min}$ in cold lysis buffer. Protein concentrations were determined with the standard Bradford method. Equal amounts of protein $(40 \mu \mathrm{g} /$ lane $)$ for each sample were electrophoresed through a $10 \%$ SDS-PAGE gel, and then electrotransferred to nitrocellulose membranes (Amersham, Uppsala, Sweden) by a semi-dry transferor. The membranes were blocked in $5 \%$ skimmed milk in PBS-T containing $0.05 \%$ Tween-20 at RT for $2 \mathrm{~h}$, and then incubated at RT for $2 \mathrm{~h}$ with corresponding primary antibodies including anti-Pim- 1 , anti- $\beta$-actin, 

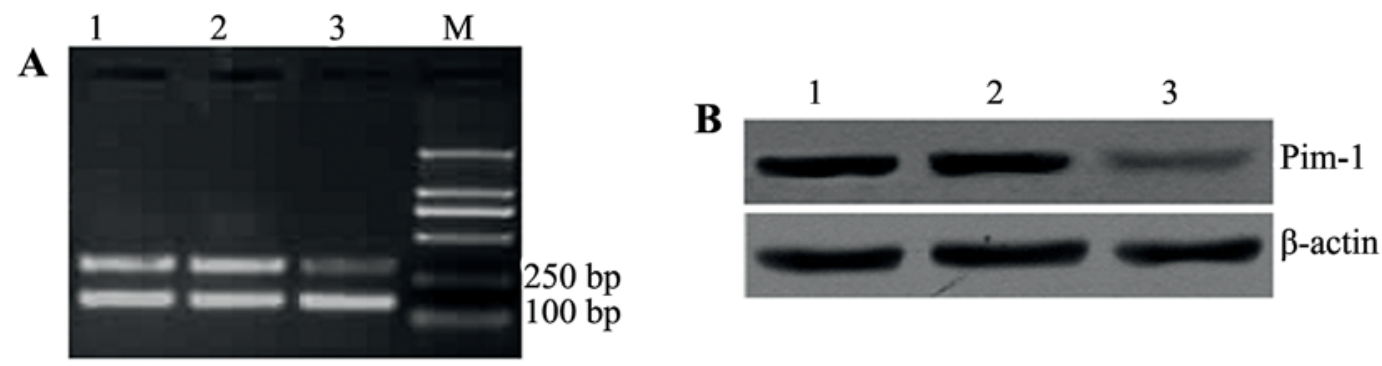

C

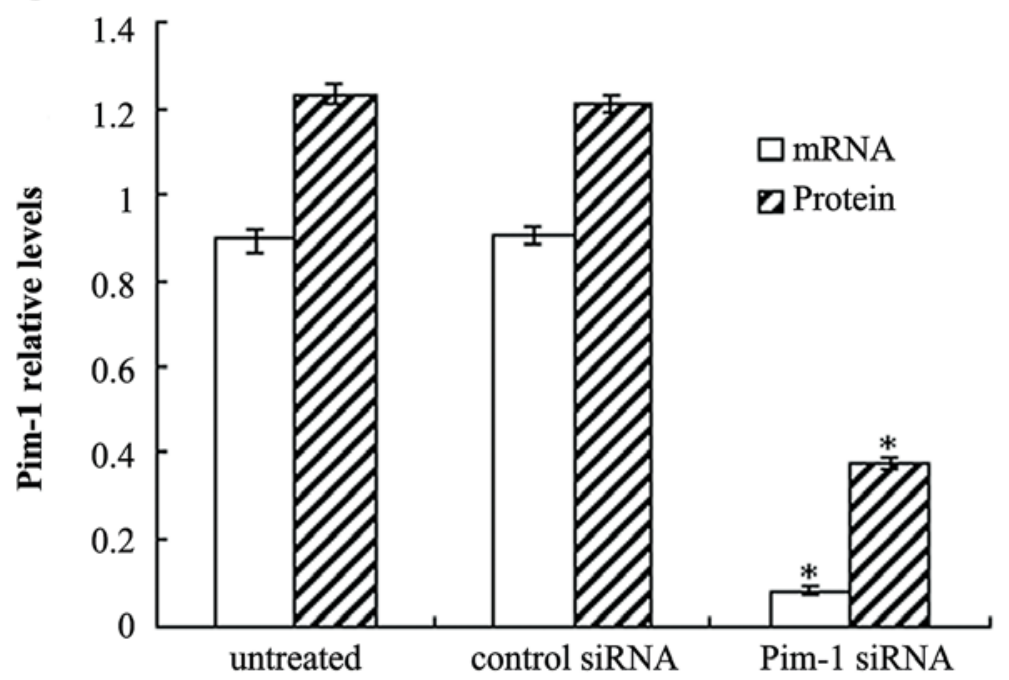

D

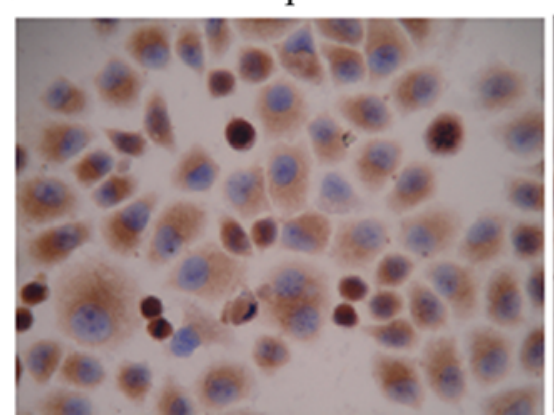

2

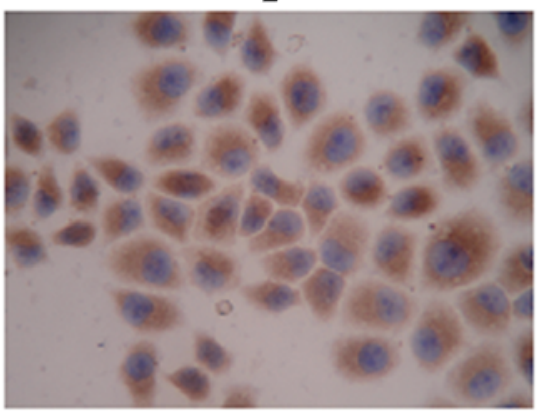

3

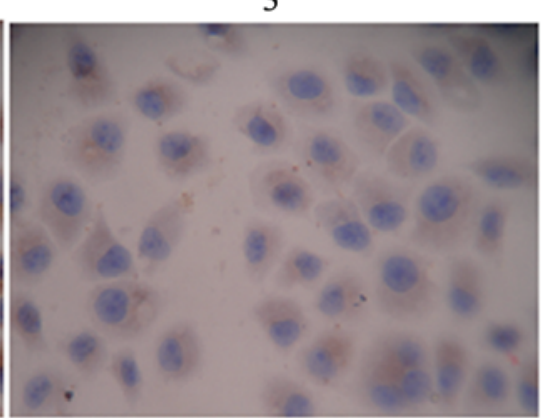

Figure 1. Effect of Pim-1 siRNA on Pim-1 level in EC9706 cells. (A) Pim-1 mRNA expression was analyzed by RT-PCR; (B) Western blot analysis was performed with antibodies to Pim-1 and B-actin (internal control) in EC9706 cells, respectively. (C) Semi-quantitative values of three independently repeated RT-PCR and Western blotting experiments were statistically analyzed by Gene Tools software, are expressed as means \pm SD. ${ }^{*}<<0.05$, compared to those of untreated and control siRNA. (D) Expression of Pim-1 was analyzed by immunocytochemistry method and cytoplasm localization was investigated. 1: untreated group; 2: control siRNA group; 3: Pim-1 siRNA group; M: Molecular marker D2000 (Tiangen Biotech, China)

anti-phospho-Akt at Ser473, anti-Akt, anti-phospho-Bad at Ser112 and Ser136, anti-Bad, and anti-cleaved caspase-9 (all from Santa Cruz Company) diluted in $1 \%$ skimmed milk in PBS-T, respectively, followed by incubation with horseradish peroxidase-conjugated secondary antibodies (anti-goat, antirabbit or anti-mouse) (Santa Cruz Company). For detection, DAB solution was used to develop the bands of specific proteins on the membranes according to the manufacturer's instructions. Quantification of band intensity was performed using Gene Tools (UVP, Inc.).

Statistical analysis. The data were performed by one-way analysis of variance using SPSS version 13.0 (SPSS, Chicago, IL, USA). Summary statistics were expressed as means \pm standard deviations, except as otherwise stated. In all statistical analyses, $\mathrm{P}<0.05$ was considered statistically significant, and all $\mathrm{P}$-values were two-sided.

\section{Results}

Decrease of Pim-1 level mediated by Pim-1 siRNA. Pim-1 siRNA and control siRNA were transfected into esophageal squamous cell carcinoma cell line EC9706 cells. EC9706 cells were divided into three groups including untreated, control siRNA and Pim-1 siRNA groups. Pim-1 mRNA level was investigated by RT-PCR method, and Pim-1 protein level was analyzed by Western blot and immunocytochemical methods, respectively. The results demonstrated that both 


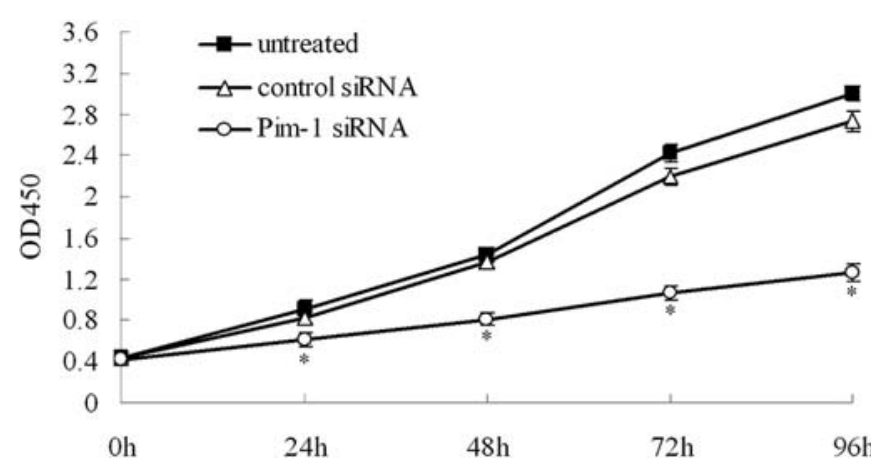

Figure 2. Pim-1 siRNA inhibits the proliferation of EC9706 cells Proliferations of EC9706 cells untreated and transfected with Pim-1 siRNA and control siRNA were detected by CCK8 kit. The proliferation of EC9706 cells was obviously inhibited after Pim-1 siRNA treatment compared to those of EC9706 cells untreated and transfected with control siRNA $(\mathrm{P}<0.01)$. ${ }^{*} \mathrm{P}<0.05$, compared to those of EC9706 untreated and transfected with control siRNA.

pim-1 mRNA and protein were signicantly decreased after Pim-1 siRNA treatment, compared to those of untreated and control siRNA (Fig. 1), indicating that Pim-1 siRNA effectively down-regulated Pim-1 level in EC9706 cells.
Cell proliferation assay. To determine whether siRNA against Pim-1 in EC9706 cells affects cellular proliferation, we utilized the CCK-8 kit, a kind of viable cell count, as a substitute for MTT to analyze the effect of Pim-1 siRNA on proliferation of EC9706 cells. As shown in Fig. 2, there were no obvious differences in proliferation rates of EC9706 cells untreated and transfected with control siRNA ( $>>0.05)$. However, the growth of EC9706 cells transfected with Pim-1 siRNA was inhibited significantly $(\mathrm{P}<0.05)$ compared to that of EC9706 cells untreated and transfected with control siRNA. These results demonstrated that introducing of Pim-1 siRNA was able to clearly inhibit the proliferation of EC9706 cells.

Flow cytometry analysis for cell apoptosis. It is well known that cell apoptosis play a pivotal role in the occurrence and development of tumors. Whether down-regulation of Pim-1 expression is involved in the apoptosis of EC9706 cells. In this study, flow cytometry was utilized to analyze the apoptosis of EC9706 cells mediated by Pim-1 siRNA. EC9706 cells untreated and transfected with control siRNA served as negative controls. The results showed that Pim-1 siRNA clearly induced cell apoptosis in EC9706 cells $(\mathrm{P}<0.05)$. After transfection with Pim-1 siRNA, the proportions of

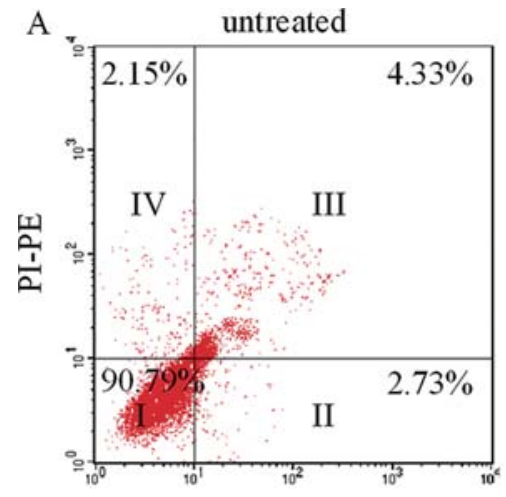

B

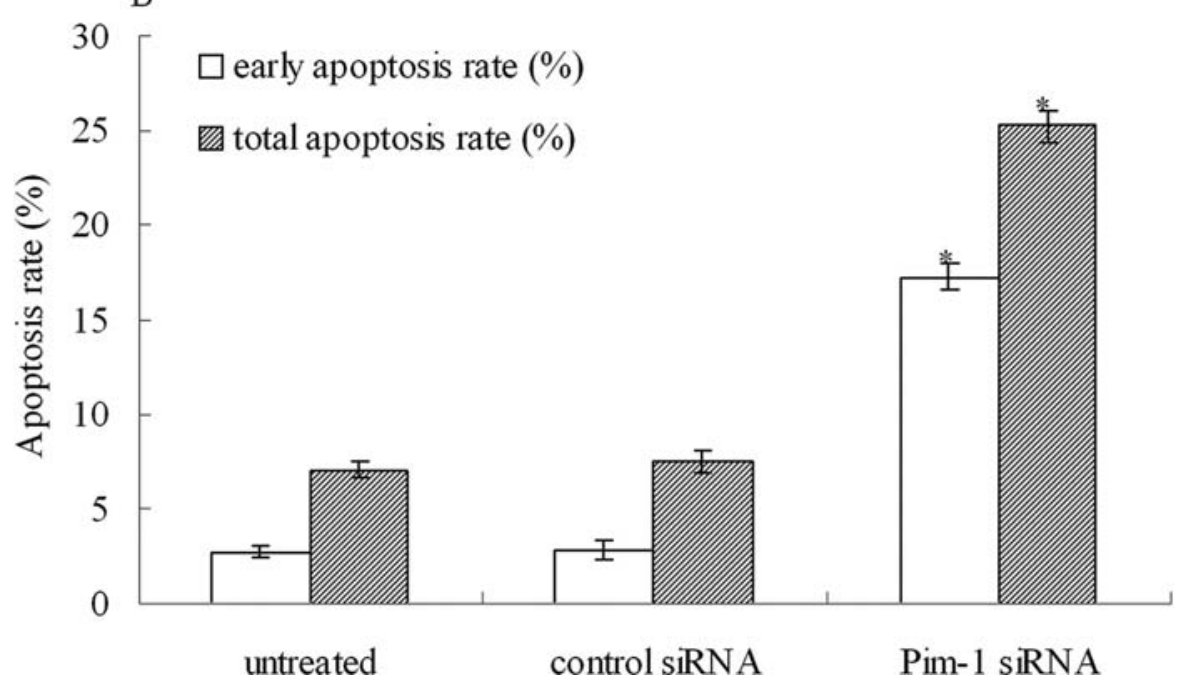

Figure 3. Cell apoptosis mediated by Pim-1 siRNA in EC9706 cells. EC9706 cells were seeded in six-well plate containing 10\% FBS-RPMI-1640 and cultured overnight. (A) EC9706 Cells untreated and treated with Pim-1 siRNA and control siRNA for 48 h, followed by apoptosis assay using the Annexin V-FITC apoptosis detection kit. Cells untreated and transfected with control siRNA were served as controls. (B) Statistical analysis results of early apoptosis ratio and total apoptosis ratio. Results derived from three independent experiments are expressed as means \pm SD. ${ }^{*} \mathrm{P}<0.05$, compared to those of untreated and control siRNA. 


\section{untreated control siRNA Pim-1 siRNA}

A
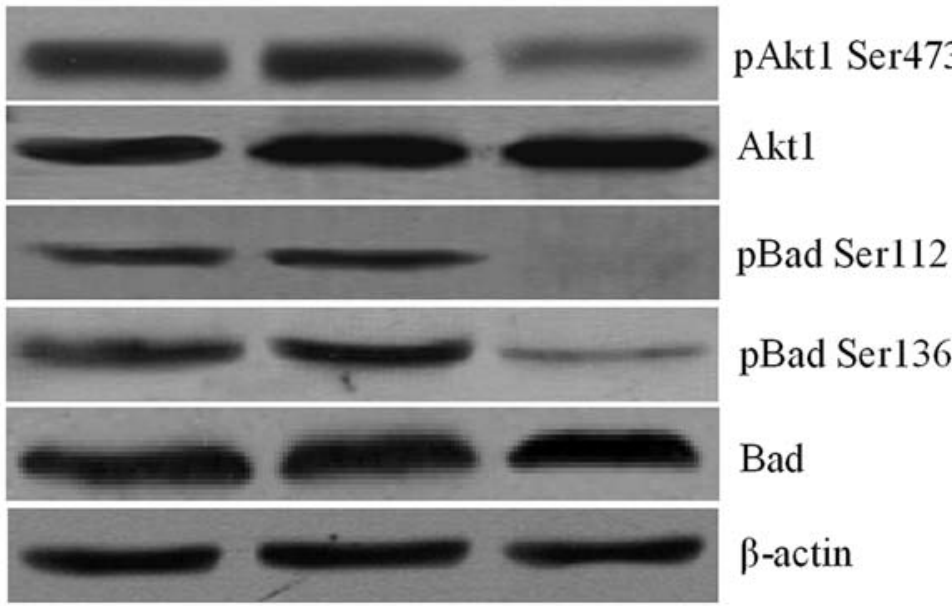

pBad Ser136

Bad

$\beta$-actin

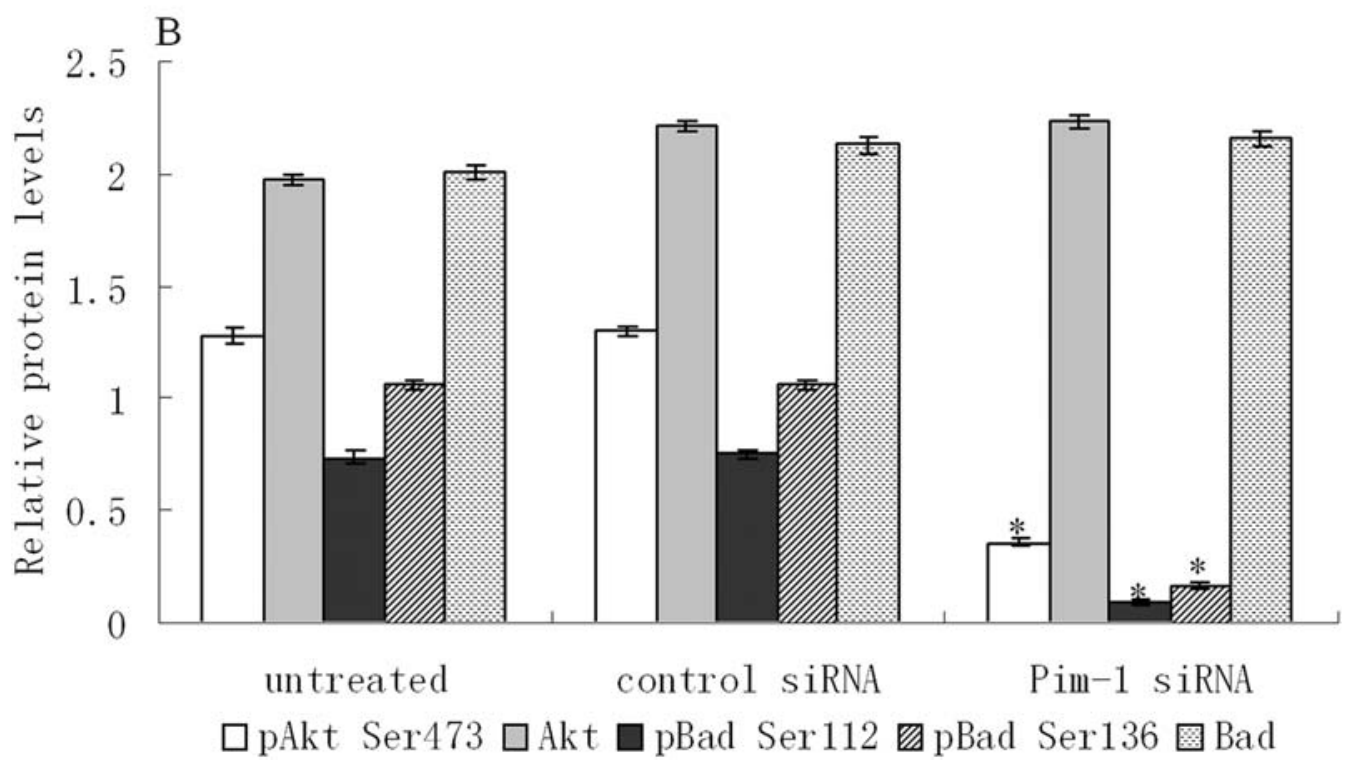

Figure 4. Detection of Akt1 and Bad protein phosphorylation levels. (A) Western blot analysis for relative expressions of pAkt1 Ser473 phosphorylation, Akt1, pBad Ser112 and Ser136 phosphorylation and Bad. (B) Statistical analysis for the above-mentioned proteins. Results from three independently repeated experiments are expressed as means $\pm \mathrm{SD}$. ${ }^{*} \mathrm{P}<0.05$, compared to those of EC9706 cells untreated and transfected with control siRNA.

positive cells for Annexin $\mathrm{V}$ and propidium iodide (region II) $(17.27 \%)$ were evidently increased $(\mathrm{P}<0.05)$, compared to EC9706 cells untreated and transfected with control siRNA (2.73 and $2.80 \%$, respectively), and the tendency of total cell apoptosis rates was consistent with that of early cell apoptosis rate (Fig. 3). However, there was no difference in the early apoptosis rate and total apoptosis rate between EC9706 cells untreated and transfected with control siRNA ( $>>0.05)$, suggesting the introduction of Pim-1 siRNA has an inductive effect on apoptosis of EC9706 cells.

Akt1 and Bad protein phosphorylation analysis. Cell lysates from EC9706 Cells untreated and treated with Pim-1 siRNA and control siRNA for $48 \mathrm{~h}$ were extracted, followed by Western blot analysis for Akt1 and Bad protein phosphorylation. The results revealed that the level of phosphorylation of Akt1 at Ser473 was decreased in EC9706 cells transfected with Pim-1 siRNA, compared to that in EC9706 cells untreated and transfected with control siRNA, while there was no change in the total Akt1 protein level (Fig. 4). These results indicate that Pim-1 siRNA somehow mediated the inhibition of the phosphorylation of Akt at Ser473, without affecting total levels of Akt1. In addition, Pim-1 siRNA treatment resulted in less Bad phosphorylation at both Ser112 and Ser136 in EC9706 cells, but not changing the level of total Bad protein (Fig. 4). These results are in accordance with the decreased Akt1 level mediated by Pim-1 siRNA, indicating that Pim-1 siRNA-induced cell apoptosis is mediated at least in part by the Akt1-Bad apoptotic pathway. However, the precise mechanism for these events remains to be elucidated.

Caspase-3/9 activities and expressions analysis. An important component of the apoptotic machinery is the proteolytic system of caspases. Therefore, we investigated the activation of caspase- 3 and caspase- 948 h after Pim- 1 siRNA treatment, followed by analysis for cleaved caspase- 3 and -9 proteins levels by Western blot. We found that caspase-3/9 activities significantly increased in EC9706 cells transfected with Pim-1 siRNA compared to those in EC9706 cells untreated and 


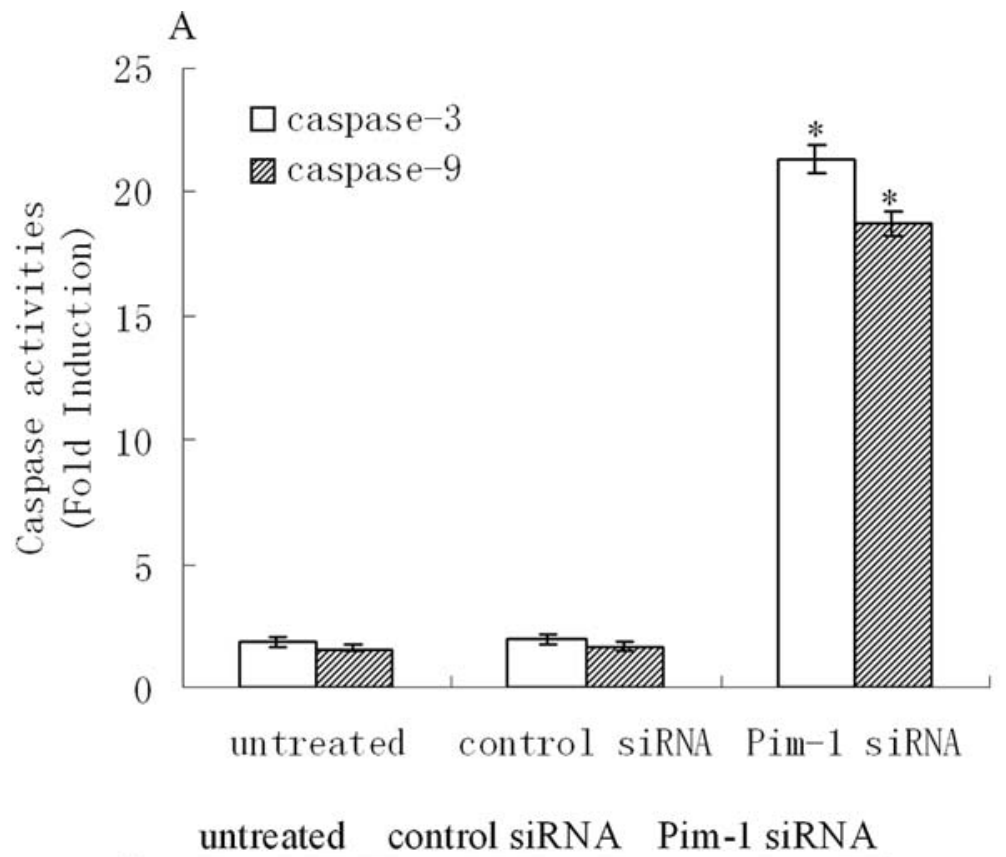

B
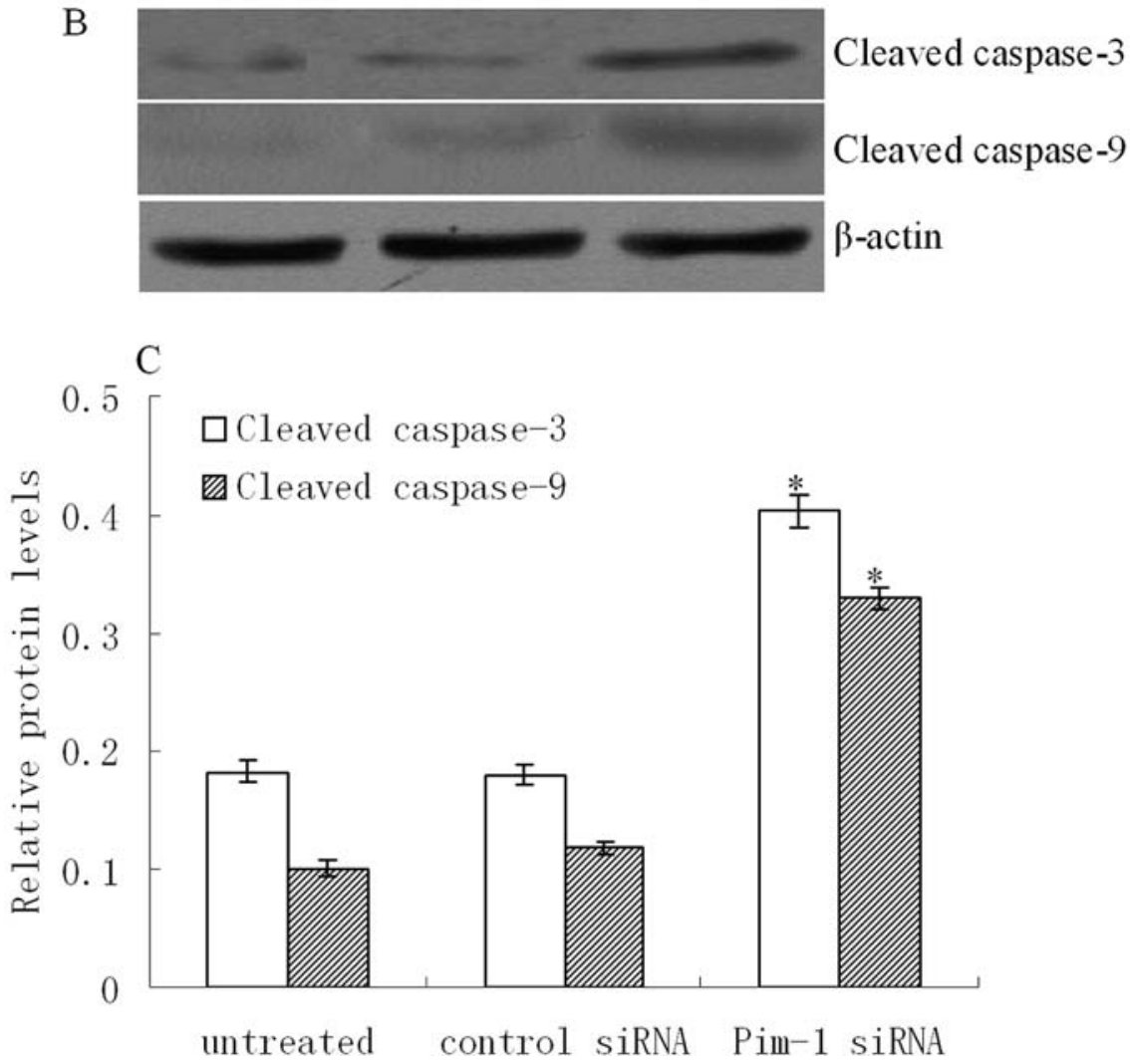

Figure 5. Effects of Pim-1 siRNA on caspase-3/-9 activities and expressions. (A) Caspase-3/-9 activities were measured after Pim-1 siRNA treatment. Ac-DEVD-AMC and Ac-LEHD-AFC were used for substrates of caspase-3 and -9, respectively. Caspase activities were analyzed as described in Materials and methods. (B) Western blot analysis for cleaved caspase-3/-9 expressions. (C) Statistical analysis for cleaved caspase-3/-9 expressions. Results from three independently repeated experiments are expressed as means \pm SD. ${ }^{*}<0.05$, compared to those of EC9706 cells untreated and transfected with control siRNA.

transfected with control siRNA, there were no differences in the activities of caspase-3/9 in EC9706 cells untreated and transfected with control siRNA (Fig. 5A). In addition, the result of Western blot demonstrated that cleaved caspase-3/9 expression levels were clearly elevated after Pim-1 siRNA treatment (Fig. 5B and C), suggesting that Pim-1 siRNA could activate the mitochondrial pathway of apoptosis, and further evoke the apoptosis of EC9706 cells.

\section{Discussion}

Provirus integration site for Moloney murine leukemia virus (Pim-1) is a proto-oncogene that encodes a $35 \mathrm{kDa}$ cytoplasmic serine/threonine kinase with multiple cellular functions involving the regulation of cell apoptosis, cell progression, and transcription via the phosphorylation of target protein (23). More and more evidence has demonstrated that pim-1 
kinase plays an important role in tumor progression, including prostatic cancer, laryngeal cancer, lymphocytic leukemia, and head and neck squamous cell carcinomas (14,24-29). However, to date, the role of Pim-1 in the development of ESCC has not yet been investigated. To our knowledge, this is the first comprehensive description of possible molecular regulation mechanism of cell apoptosis mediated by downregulation of Pim-1 expression. Therefore, Pim-1 siRNA was used to interfere with Pim-1 expression of ESCC cell line EC9706 cells, and cell apoptosis was analyzed by flow cytometry, to further explore the possible molecular mechanism of apoptosis. In this study, EC9706 cells untreated and transfected with Pim-1 siRNA and control siRNA were harvested for analysis of Pim-1 expression level. The results revealed that Pim-1 expression level was markedly decreased after Pim-1 siRNA treatment, suggesting that Pim-1 siRNA could effectively down-regulate the Pim-1 expression level. Further, the results of cell proliferation and apoptosis demonstrated that Pim-1 siRNA could clearly inhibit cell proliferation and induce cell apoptosis in EC9706 cells, suggesting that Pim-1 plays a central role in the occurrence and development of ESCC, however its precise mechanism for these events remains unknown.

Phosphoinositol-3-kinase (PI3K)/Akt signaling pathway plays an essential role in transmitting signals from growth factors to cell death and cell cycle machineries (30). Currently, the PI3K/Akt pathway has attracted much attention because of its role in tumor cell survival. This pathway plays a major role not only in tumor development but also in the tumor potential response to cancer treatment. Akt protein regulates the function of numerous substrates involved in the regulation of cell survival, cell cycle progression, cell apoptosis and cell proliferation. Akt activation has been documented to be a frequent event in human colon cancer. In addition, this study also suggests that apoptosis inhibition during colon cancer carcinogenic process can be attributed, at least partially, to Akt (31). Moreover, it has been reported that Akt phosphorylation status in human colon carcinoma correlates with cell proliferation and apoptosis inhibition (32). We put forward the question whether Pim-1 siRNA-mediated cell apoptosis is closely associated with the status of Akt phosphorylation. Thus, in this study, our results revealed that the level of phosphorylation of Akt1 at Ser473 was clearly decreased in EC9706 cells transfected with Pim-1 siRNA, compared to that in EC9706 cells untreated and transfected with control siRNA, while there was no change in the total Akt1 protein level, suggesting Pim-1 siRNA somehow mediated the inhibition of the phosphorylation of Akt at Ser473, further affecting the activation of Akt pathway, which was consistent with the result of prostate cancer from Hu et al (33).

Akt promoted growth factor-mediated cell survival both directly and indirectly. Bad is a pro-apoptotic protein of the Bcl-2 family. Akt could phosphorylated Bad on Ser136 making Bad dissociate from the Bcl-2/Bcl-X complex and losing the pro-apoptotic function (33). Notably, Akt is likely to send survival signals by phosphorylating multiple downstream targets, including the Bcl-2 family member Bad (34) and the cell death pathway enzyme caspase-9 (35). Further, we examined the Bad phosphorylation status; the results demonstrated that Pim- 1 siRNA treatment resulted in less Bad phosphorylation at both Ser112 and Ser136 in EC9706 cells, but not changing the level of total Bad protein. These results are in accordance with the decreased Akt1 level mediated by Pim-1 siRNA, indicating that Pim-1 siRNAinduced cell apoptosis is mediated at least in part by the AktBad apoptotic pathway, although these studies are disputed and the mechanism of action is unclear. For further elucidating molecular regulation mechanism of Akt-inducing cell apoptosis mediated by Pim-1 siRNA in EC9706 cells, the activities and expressions of cell apoptosis-related gene caspase-3/-9 was detected, we found that the activities of caspase-3/-9 and the expressions cleaved caspase-3/-9 were all clearly enhanced after transfection with Pim-1 siRNA, which may be a main incentive for cell apoptosis in EC9706 cells.

In conclusion, our results demonstrated that Pim- 1 siRNA could effectively down-regulate the level of Pim-1 expression, markedly inhibit cell proliferation and induce cell apoptosis. Further, evoking the inhibition of Akt1 phosphorylation at Ser 473 and the decrease of phosphorylation of Bad at Ser 112 and Ser 136, and then elevating the activities and expressions of cleavage of caspase-3/-9 and activating the mitochondrial apoptotic pathway, which further substantiates that Pim-1 kinase may be suitable for molecular therapy target in the clinical treatment of patients with ESCC.

\section{References}

1. Iwanski GB, Block A, Keller G, Muench J, Claus S, Fiedler W and Bokemeyer C: Esophageal squamous cell carcinoma presenting with extensive skin lesions: a case report. J Med Case Rep 2: 115, 2008.

2. Shimada H, Nabeya Y, Okazumi S, Matsubara H, Shiratori T, Gunji Y, Kobayashi S, Hayashi $\mathrm{H}$ and Ochiai T: Prediction of survival with squamous cell carcinoma antigen in patients with resectable esophageal squamous cell carcinoma. Surgery 133: 486-494, 2003.

3. Pisani P, Parkin DM, Bray F and Ferlay J: Estimates of the worldwide mortality from 25 cancers in 1990. Int J Cancer 83: 18-29, 1999.

4. Enzinger PC and Mayer RJ: Esophageal cancer. N Engl J Med 349: 2241-2252, 2003

5. Cuypers HT, Selten G, Quint W, Zijlstra M, Maandag ER, Boelens W, van Wezenbeek P, Melief C and Berns A: Murine leukemia virus-induced T-cell lymphomagenesis: integration of proviruses in a distinct chromosomal region. Cell 37: 141-150, 1984.

6.van der Lugt NM, Domen J, Verhoeven E, Linders K, van der Gulden H, Allen J and Berns A: Proviral tagging in E mu-myc transgenic mice lacking the Pim-1 proto-oncogene leads to compensatory activation of Pim-2. EMBO J 14: 2536-2544, 1995.

7. Wang Z, Bhattacharya N, Weaver M, Petersen K, Meyer M, Gapter L and Magnuson NS: Pim-1: a serine/threonine kinase with a role in cell survival, proliferation, differentiation and tumorigenesis. J Vet Sci 2: 167-179, 2001.

8. Bachmann $\mathrm{M}$ and Moroy T: The serine/threonine kinase Pim-1. Int J Biochem Cell Biol 37: 726-730, 2005

9. Muraski JA, Rota M, Misao Y, Fransioli J, Cottage C, Gude N, Esposito G, Delucchi F, Arcarese M, Alvarez R, Siddiqi S, Emmanuel GN, Wu W, Fischer K, Martindale JJ, Glembotski CC, Leri A, Kajstura J, Magnuson N, Berns A, Beretta RM, Houser SR, Schaefer EM, Anversa P and Sussman MA: Pim-1 regulates cardiomyocyte survival downstream of Akt. Nat Med 13: 1467-1475, 2007

10. Zemskova M, Sahakian E, Bashkirova S and Lilly M: The PIM1 kinase is a critical component of a survival pathway activated by docetaxel and promotes survival of docetaxel-treated prostate cancer cells. J Biol Chem 283: 20635-20644, 2008. 
11. Willert M, Augstein A, Poitz DM, Schmeisser A, Strasser RH and Braun-Dullaeus RC: Transcriptional regulation of Pim-1 kinase in vascular smooth muscle cells and its role for proliferation. Basic Res Cardiol 105: 267-277, 2010.

12. Zhao Y, Hamza MS, Leong HS, Lim CB, Pan YF, Cheung E, Soo KC and Iyer NG: Kruppel-like factor 5 modulates p53independent apoptosis through Pim1 survival kinase in cancer cells. Oncogene 27: 1-8, 2008.

13. Andina N, Didichenko S, Schmidt-Mende J, Dahinden CA and Simon HU: Proviral integration site for Moloney murine leukemia virus 1 , but not phosphatidylinositol-3 kinase, is essential in the antiapoptotic signaling cascade initiated by IL-5 in eosinophils. J Allergy Clin Immunol 123: 603-611, 2009.

14. Chen LS, Redkar S, Bearss D, Wierda WG and Gandhi V: Pim kinase inhibitor, SGI-1776, induces apoptosis in chronic lymphocytic leukemia cells. Blood 114: 4150-4157, 2009.

15. Chen J, Kobayashi M, Darmanin S, Qiao Y, Gully C, Zhao R, Kondo S, Wang H, Yeung SC and Lee MH: Hypoxia-mediated up-regulation of Pim-1 contributes to solid tumor formation. Am J Pathol 175: 400-411, 2009.

16. Chen J, Kobayashi M, Darmanin S, Qiao Y, Gully C, Zhao R, Yeung SC and Lee MH: Pim-1 plays a pivotal role in hypoxiainduced chemoresistance. Oncogene 28: 2581-2592, 2009.

17. Shah N, Pang B, Yeoh KG, Thorn S, Chen CS, Lilly MB and Salto-Tellez M: Potential roles for the PIM1 kinase in human cancer - a molecular and therapeutic appraisal. Eur J Cancer 44: 2144-2151, 2008.

18. Reiser-Erkan C, Erkan M, Pan Z, Bekasi S, Giese NA, Streit S, Michalski CW, Friess $\mathrm{H}$ and Kleeff J: Hypoxia-inducible protooncogene Pim-1 is a prognostic marker in pancreatic ductal adenocarcinoma. Cancer Biol Ther 7: 1352-1359, 2008

19. Warnecke-Eberz U, Bollschweiler E, Drebber U, Pohl A, Baldus SE, Hoelscher AH and Metzger R: Frequent downregulation of pim-1 mRNA expression in non-small cell lung cancer is associated with lymph node metastases. Oncol Rep 20: 619-624, 2008

20. He HC, Bi XC, Zheng ZW, Dai QS, Han ZD, Liang YX, Ye YK, Zeng GH, Zhu G and Zhong WD: Real-time quantitative RTPCR assessment of PIM-1 and hK2 mRNA expression in benign prostate hyperplasia and prostate cancer. Med Oncol 26: 303-308, 2009.

21. Tian F, Zang WD, Hou WH, Liu HT and Xue LX: Nuclear factor- $\kappa \mathrm{B}$ signaling pathway constitutively activated in esophageal squamous cell carcinoma cell lines and inhibition of growth of cells by small interfering RNA. Acta Biochim Biophys Sin (Shanghai) 38: 318-326, 2006.

22. Hou G, Xue L, Lu Z, Fan T, Tian F and Xue Y: An activated mTOR/p70S6K signaling pathway in esophageal squamous cell carcinoma cell lines and inhibition of the pathway by rapamycin and siRNA against mTOR. Cancer Lett 253: 236-248, 2007.
23. Meeker TC, Nagarajan L, ar-Rushdi A, Rovera G, Huebner K and Croce CM: Characterization of the human PIM-1 gene: a putative proto-oncogene coding for a tissue specific member of the protein kinase family. Oncogene Res 1: 87-101, 1987.

24. Rainio EM, Sandholm J and Koskinen PJ: Cutting edge: Transcriptional activity of NFATc1 is enhanced by the Pim-1 kinase. J Immunol 168: 1524-1527, 2002.

25. Roh M, Gary B, Song C, Said-Al-Naief N, Tousson A, Kraft A, Eltoum IE and Abdulkadir SA: Overexpression of the oncogenic kinase Pim-1 leads to genomic instability. Cancer Res 63: 8079-8084, 2003.

26. Peltola KJ, Paukku K, Aho TL, Ruuska M, Silvennoinen O and Koskinen PJ: Pim-1 kinase inhibits STAT5-dependent transcription via its interactions with SOCS1 and SOCS3. Blood 103: 3744-3750, 2004

27. Cibull TL, Jones TD, Li L, Eble JN, Ann Baldridge L, Malott SR, Luo Y and Cheng L: Overexpression of Pim-1 during progression of prostatic adenocarcinoma. J Clin Pathol 59: 285-288, 2006.

28. Choi JY, Cho SI, Do NY, Kang CY and Lim SC: Clinical significance of the expression of galectin-3 and Pim-1 in laryngeal squamous cell carcinoma. J Otolaryngol Head Neck Surg 39: 28-34, 2010.

29. Beier UH, Weise JB, Laudien M, Sauerwein H and Gorogh T: Overexpression of Pim-1 in head and neck squamous cell carcinomas. Int J Oncol 30: 1381-1387, 2007.

30. Carpenter CL and Cantley LC: Phosphoinositide kinases. Curr Opin Cell Biol 8: 153-158, 1996.

31. Roy HK, Olusola BF, Clemens DL, Karolski WJ, Ratashak A, Lynch HT and Smyrk TC: AKT proto-oncogene overexpression is an early event during sporadic colon carcinogenesis. Carcinogenesis 23: 201-205, 2002.

32. Itoh N, Semba S, Ito M, Takeda H, Kawata S and Yamakawa M: Phosphorylation of Akt/PKB is required for suppression of cancer cell apoptosis and tumor progression in human colorectal carcinoma. Cancer 94: 3127-3134, 2002.

33. Hu XF, Li J, Vandervalk S, Wang Z, Magnuson NS and Xing PX: PIM-1-specific mAb suppresses human and mouse tumor growth by decreasing PIM-1 levels, reducing Akt phosphorylation, and activating apoptosis. J Clin Invest 119: 362-375, 2009.

34. Datta SR, Dudek H, Tao X, Masters S, Fu H, Gotoh Y and Greenberg ME: Akt phosphorylation of BAD couples survival signals to the cell-intrinsic death machinery. Cell 91: 231-241, 1997.

35. Cardone MH, Roy N, Stennicke HR, Salvesen GS, Franke TF, Stanbridge E, Frisch S and Reed JC: Regulation of cell death protease caspase-9 by phosphorylation. Science 282: 1318-1321, 1998. 